\title{
Relationship between organizational justice and trust among nurses in Assiut University Hospital
}

\author{
Asmaa Mohammed Ahmed, Kawther Abd-El Motagely Fadel, Soad Ahmed Ghallab \& Nahed Shawkat \\ Abo El Magd. \\ Nursing Administration Dep, Faculty of Nursing South Valley University, Qena, Egypt, \\ Public Health And Community Medicine Dep., Faculty of Medicine - Assiut University, Assiut, Egypt, \\ Nursing Administration Dep, Faculty of Nursing, Assiut University, Assiut, Egypt, \\ Nursing Administration Dep, Faculty of Nursing, Assiut University, Assiut, Egypt.
}

\begin{abstract}
In the recent years, increasing attention has been paid to the issue of organizational justice and its impacts on organizational outcomes. The concept of justice is central to understanding a wide range of human behavior in the organizational setting. Organizational justice refers to employee's perceptions of fairness in the workplace. It has shown to be associated with several outcomes such as job satisfaction, work motivation This study was amid to assessing the organizational justice and trust in three university hospitals at Assuit. Relationship between organizational justice and trust Research design: was a cross-sectional descriptive correlation research design. Setting: The study was carried out at Assiut University Hospitals (main, pediatric and woman reproductive health hospital) Subject: included a representative sample (727) from the total number of nurses who working in the three hospitals. Tools: Three tools were used for data collection; Organizational Justice Questionnaire, and Organizational Trust Scale. Results revealed that there was a significant positive relationship between organizational justice and trust conclusions: The nurses' perception of organizational justice was significantly correlated with organizational trust. Recommendation: Organizational management should apply and create what is called climate of fairness and trust through working within a team contribution.
\end{abstract}

\section{Keywords: Organizational Justice \& Organizational Trust.}

\section{Introduction}

Perceptions of organizational justice constitute an important heuristic in organizational decisionmaking, as research relates it to job satisfaction, turnover, leadership, organizational citizenship, organizational commitment, trust, customer satisfaction, job performance, employee theft, role breadth, alienation, and leader-member exchange (Johnson, 2007).

Organizational justice refers to the study of fairness within organizational settings and originates from work in social psychology aimed at understanding fairness issues in social interactions (Ponnu \&Chuah; 2010). Organizational justice is essentially the perception that employees of an organization are being treated fairly. It can take several forms, ranging from the perceptions of fairness of policies and procedures to how the distribution of rewards and punishments are viewed and finally to simply being treated with courtesy and respect (Mcnabb, 2009).

Three main proposed components of organizational justice are distributive, procedural, and interactional justice (which includes informational and interpersonal justice).The relationship between trust and organizational justice perceptions is based on reciprocity. Trust in the organization is built when the employees belief that since current organizational decisions are fair then future organizational decisions will be fair. The continuance of employee`s trust in the organization and the organization continuing to meet the employee's expectations of fairness creates the reciprocal relationship between trust and organizational justice (DeConick, 2010): Trust is defined as "the willingness of a party to be vulnerable to the actions of another party" (Afsar \& Saeed, 2010).

Robbins and Judge (2009) indicated that three types of trust exist in organizational relationships. The first type is deterrence-based trust and is usually at the beginning of any organizational relationship. Deterrence-based trust focuses on fear of reprisal if trust is not in place. Deterrence-based trust works when leadership implements punishment with specific consequences (Ritter and Lord, 2007).

The second type of trust and the most common in organizations is knowledge based and relies on the predictability of interactions that occur over time. The parties recognize how responds to situations and trust grows from this recognition and relationship. Identification-based trust is the third type and routinely arises out of a long relationship such as with married couples who recognize how the other will respond (Robbins and Judge, 2009). 
Turner (2010) set out behaviors which represent foundations that direct trusting relationships. The leaders and teams need to recognize behaviors that demonstrate trust within the organization and help train the teams to assess the team members and reinforce the use of the behaviors in all activities. The behaviors that demonstrate trust are: talk straight, be honest, demonstrate respect, create transparency ,right wrongs, apologize when necessary, show loyalty, give credit freely, deliver results and complete tasks correctly, confront reality, take issues head one, practice accountability, listen before speaking, understand and diagnose, keep commitments, and extend trust abundantly.

Organizational scholars have suggested repeatedly that when employees feel trusted by management, they will experience positive attitudes and deliver better performance (Young, 2009) In addition Salamon and Robinson (2008) introduced the concept of "felt trustworthiness" and "felt trust," respectively, which they conceptualized as employees' perception of their leaders' trust in them.

Being supervised by someone that one does not trust can be psychologically distressing and this distress will likely affect one's job attitudes one such attitude is affective organizational commitment. (Dirks and Ferrin, 2002).

\section{Significance of the study}

Organizational justice and trust has been shown to influence other work related outcomes, including job satisfaction and organizational commitment, thus making it an issue that deserves further attention (Wong et al., 2004).

However, there is a lack of research in the area of the relation between organizational justice and trust. Therefore, this study is an attempt in this direction, through studying the relation between organizational justice and trust.

\section{Aims of the study}

Are to Assessing the organizational justice and trust in three university hospitals at Assuit.

Study the relationship between organizational justice and trust

\section{Research Questions}

Is there positive correlation between distributive justice and organizational trust?

Is there positive correlation between procedural justice and organizational trust?

Is there positive correlation between procedural justice and organizational trust?

\section{Subjects and methods}

This research will be portrayed according to the following:

- Technical design

- Administrative design

- Operational design

- Statistical design.

Technical Design

This design involves the study design, setting, sample, and tools of data collection

Study design

This study is cross-sectional descriptive correlation research design.

\section{Setting}

The study was conducted at Assiut University Hospitals (main, pediatric and woman reproductive health hospital). With bed capacity of 2811 beds.

\section{Subject}

Subject of the present study included a representative sample from the total number of staff nurses working at Assiut University Hospitals. Sample size determined according to Ryan schedule (2002).

\begin{tabular}{|l|c|c|}
\hline \multicolumn{1}{|c|}{ Hospital } & $\begin{array}{c}\text { Total staff } \\
\text { nurses }\end{array}$ & $\begin{array}{c}\text { Sample } \\
\text { size }\end{array}$ \\
\hline Main hospital & 1591 & 417 \\
\hline $\begin{array}{l}\text { Pediatric } \\
\text { hospital }\end{array}$ & 258 & 177 \\
\hline $\begin{array}{l}\text { Woman } \\
\text { reproductive } \\
\text { health hospital }\end{array}$ & 184 & 133 \\
\hline Total & 2033 & 727 \\
\hline
\end{tabular}

\section{Data collection tools}

The data needed for the study was collected using three different tools

\section{Organizational justice Questionnaire}

It comprised of two parts:

Part I: Socio demographic data sheet: was designed to gather data about age, gender, marital status, educational level, job position, and years of experience, monthly salary and incentives received

Part II: Organizational justice Questionnaire: used for assessment of the current state of organizational justice. It was developed by (Johnson, 2007). The tool consists of 18 items categorized into three domains of organizational justice as follows: distributive justice, procedural justice, and interactional justice.

- Distributive Justice Index (DJI). The DJI is a sixitem justice scale created by (Price and Mueller, 1986) and is intended to measure respondents' perceptions of the fairness of the rewards they receive for their contributions to their work organizations. 
- Procedural Justice Measure. The six-item procedural justice created by (Moorman, 1991) for his research of organizational citizenship.

- Interactional Justice Measure. Created by (Moorman, 1991) it is six-item scale to measure interactional justice which focuses on the manager of each respondent.

The responses are on a 5-point likert scale ranging from "strongly disagree" to "strongly agree" Scores of $1,2,3,4$, or 5 .The scores of each group of items were summed-up and the total divided by the number of the items in this group, giving a mean score for each domain of the organizational Justice. These scores were converted into a percent score, and means and standard deviations were computed.

- Organizational Trust Scale: developed by (Tammy, 2002) it included information about the primary reasons for lack of trust and ways to develop and maintain trust. The tool consists of 34 items. The responses are on a 5-point likert scale ranging from "strongly disagree" to "strongly agree" Scores of 1, 2, 3,4 , or 5 .

\section{II- Administrative Design}

1-An official approval to carry out the study were obtained from different authorities of Assiut University Hospitals (Nursing directors, heads of the selected departments) to be able to collect the necessary data for the present study.

2- Oral agreement was obtained from all participant nurses in the study. Confidentiality of obtained data was assured, the purpose, nature, and the aim of the study was explained before starting data collection.

\section{Operational design}

\section{Preparatory phase}

This phase will include the following

1 - Reviewing the available literature concerning the topic of the study

2- An Arabic translation of all study tools will be done.

\section{Pilot study}

A pilot study was fulfilled to test the questionnaires clarity, feasibility, and applicability. It was carried out on $10 \%$ from total sample seventy two staff nurses from Assiut University Hospitals (main, pediatric and woman reproductive health hospital). Brief explanation of the purpose of the study was provided to every participant in the pilot study, and then she was provided with a copy of the study tools. These data collection tools were self-administered, under supervision of the investigator. Data from the pilot study were analyzed. The pilot has also served in estimating the time needed for filling the forms, and it revealed that each participant would take about half an hour for filling. Staff nurses included in the pilot study were excluded from the main study sample and tested for its reliability by using combach's alpha coefficient test it was $\alpha=0.90$

\section{Field work}

After identification of the obstacles and limitation the pilot study, and making necessary modification to insure the clarity of the scales, data collection was conducted by the investigator. The data collection took about 30 minutes for each participant. The whole duration for data collection took about six months from June to November (2012).

\section{IV.Statistical Design}

Data entry was done using Excel, 2003 computer software package, while statistical analysis was done using SPSS 16 statistical software package. Data were presented using descriptive statistics in the form of frequencies and percentages means and standard deviations for qualitative variables. Quantitative continuance data were compared using t-test in case of comparisons between two groups. ANOVA test was used in case of comparisons among more than two groups. Qualitative variables were compared using chi-square test. Statistical significance was considered at $\mathrm{p}$-value $\leq 0.05$. 


\section{Results}

Description of the study sample.

Table (1): frequency distribution of personal characteristics of study subjects $(n=727), 2011$.

\begin{tabular}{|c|c|c|c|c|c|c|c|c|c|}
\hline \multirow[t]{2}{*}{$\begin{array}{l}\text { Socio-demographic } \\
\text { characteristics }\end{array}$} & \multicolumn{2}{|c|}{$\begin{array}{l}\text { Main Hospital } \\
\quad(n=417)\end{array}$} & \multicolumn{2}{|c|}{$\begin{array}{l}\text { Pediatric } \\
\text { Hospital } \\
(\mathrm{n}=177)\end{array}$} & \multicolumn{2}{|c|}{$\begin{array}{l}\text { Woman Hospital } \\
\quad(n=133)\end{array}$} & \multicolumn{2}{|c|}{$\begin{array}{c}\text { Total } \\
(n=727)\end{array}$} & \multirow[t]{2}{*}{ P-value } \\
\hline & No. & $\%$ & No. & $\%$ & No. & $\%$ & No. & $\%$ & \\
\hline \multicolumn{9}{|l|}{ Sex } & \multirow{3}{*}{$0.000 *$} \\
\hline Male & 56 & 13.4 & 2 & 1.1 & 0 & 0.0 & 58 & 8.0 & \\
\hline Female & 361 & 86.6 & 175 & 98.9 & 133 & 100.0 & 669 & 92.0 & \\
\hline \multicolumn{9}{|l|}{ Age } & \multirow{4}{*}{$0.002 *$} \\
\hline$<40$ years & 197 & 47.2 & 110 & 62.1 & 69 & 51.9 & 376 & 51.7 & \\
\hline $40-<50$ years & 147 & 35.3 & 56 & 31.6 & 44 & 33.1 & 247 & 34.0 & \\
\hline$\geq 50$ years & 73 & 17.5 & 11 & 6.2 & 20 & 15.0 & 104 & 14.3 & \\
\hline \multicolumn{9}{|l|}{ Job } & \multirow{3}{*}{$0.001 *$} \\
\hline Head nurses & 111 & 26.6 & 37 & 20.9 & 15 & 11.3 & 163 & 22.4 & \\
\hline Nurse & 306 & 73.4 & 140 & 79.1 & 118 & 88.7 & 564 & 77.6 & \\
\hline \multicolumn{9}{|l|}{ Marital status } & \multirow{3}{*}{0.128} \\
\hline Single & 105 & 25.2 & 32 & 18.1 & 35 & 26.3 & 172 & 23.7 & \\
\hline Married & 312 & 74.8 & 145 & 81.9 & 98 & 73.7 & 555 & 76.3 & \\
\hline \multicolumn{9}{|l|}{ Qualification } & \multirow{4}{*}{$0.002 *$} \\
\hline $\begin{array}{l}\text { Secondary nursing school } \\
\text { diploma }\end{array}$ & 210 & 50.4 & 101 & 57.1 & 74 & 55.6 & 385 & 53.0 & \\
\hline Institute of nursing & 96 & 23.0 & 39 & 22.0 & 44 & 33.1 & 179 & 24.6 & \\
\hline Bachelor of nursing & 111 & 26.6 & 37 & 20.9 & 15 & 11.3 & 163 & 22.4 & \\
\hline \multicolumn{9}{|l|}{ Years of experience } & \multirow{5}{*}{$0.006 *$} \\
\hline $1-5$ years & 107 & 25.7 & 57 & 32.2 & 47 & 35.3 & 211 & 29.0 & \\
\hline $6-10$ years & 120 & 28.8 & 62 & 35.0 & 27 & 20.3 & 209 & 28.7 & \\
\hline $11-15$ years & 69 & 16.5 & 29 & 16.4 & 26 & 19.5 & 124 & 17.1 & \\
\hline$>15$ years & 121 & 29.0 & 29 & 16.4 & 33 & 24.8 & 183 & 25.2 & \\
\hline \multicolumn{9}{|l|}{ Salary } & \multirow{4}{*}{ 0.003* } \\
\hline$<500$ pound & 34 & 8.2 & 8 & 4.5 & 19 & 14.3 & 61 & 8.4 & \\
\hline 500 - 999 pound & 281 & 67.4 & 140 & 79.1 & 89 & 66.9 & 510 & 70.2 & \\
\hline$>1000$ pound & 102 & 24.5 & 29 & 16.4 & 25 & 18.8 & 156 & 21.5 & \\
\hline \multicolumn{9}{|l|}{ Fringe benefit } & \multirow{5}{*}{0.051} \\
\hline$<50$ pound & 72 & 17.3 & 14 & 7.9 & 20 & 15.0 & 106 & 14.6 & \\
\hline $50-<99$ pound & 158 & 37.9 & 81 & 45.8 & 60 & 45.1 & 299 & 41.1 & \\
\hline $100-<199$ pound & 128 & 30.7 & 53 & 29.9 & 31 & 23.3 & 212 & 29.2 & \\
\hline$\geq 200$ pound & 59 & 14.1 & 29 & 16.4 & 22 & 16.5 & 110 & 15.1 & \\
\hline
\end{tabular}

Table (2) : Mean scores of organizational justice, trust, and commitment as perceived by the studied nurses, at Assiut University Hospitals, (n=727) 2011.

\begin{tabular}{|c|c|c|c|c|}
\hline \multirow{2}{*}{ Items } & Main & Pediatric & Women & \multirow{2}{*}{ P-value } \\
\hline & Mean \pm SD & Mean \pm SD & Mean \pm SD & \\
\hline Organizational justice & \multirow[b]{2}{*}{$12.50 \pm 5.43$} & \multirow[b]{2}{*}{$13.74 \pm 6.16$} & \multirow[b]{2}{*}{$12.65 \pm 5.94$} & \multirow[b]{2}{*}{ 0.050* } \\
\hline Distributive justice & & & & \\
\hline procedural justice & $12.50 \pm 4.69$ & $14.71 \pm 5.18$ & $12.44 \pm 5.42$ & $0.000 *$ \\
\hline interactional justice & $17.35 \pm 6.45$ & $18.19 \pm 6.19$ & $16.53 \pm 6.94$ & 0.081 \\
\hline Overall justice & $42.35 \pm 13.06$ & $46.63 \pm 14.41$ & $41.62 \pm 16.25$ & $0.001 *$ \\
\hline Organizational trust & $98.15 \pm 18.80$ & $107.11 \pm 19.80$ & $96.74 \pm 24.30$ & $0.000 *$ \\
\hline
\end{tabular}

ANOVA test

* Statistical significant difference $(P<0.05)$ 
Correlation between items of organizational justice and trust at Assiut university hospitals Table (3) : Correlation between organizational justice and trust at the Main Hospital.

\begin{tabular}{|c|c|c|c|c|c|}
\hline \multicolumn{2}{|c|}{ Items } & $\begin{array}{c}\text { distributive } \\
\text { Justice }\end{array}$ & $\begin{array}{c}\text { procedural } \\
\text { Justice }\end{array}$ & $\begin{array}{c}\text { interactional } \\
\text { Justice }\end{array}$ & Overall justice \\
\hline \multirow{2}{*}{ Organizational trust } & r-value & 0.421 & 0.427 & 0.448 & 0.550 \\
\cline { 2 - 6 } & P-value & $0.000^{*}$ & $0.000^{*}$ & $0.000^{*}$ & $0.000^{*}$ \\
\hline
\end{tabular}

Pearson correlation

* Statistical significant difference $(P<0.05)$

Table (4) : Correlation between organizational justice and trust at Pediatric Hospital.

\begin{tabular}{|c|c|c|c|c|c|}
\hline \multicolumn{2}{|c|}{ Items } & $\begin{array}{c}\text { distributive } \\
\text { Justice }\end{array}$ & $\begin{array}{c}\text { procedural } \\
\text { Justice }\end{array}$ & $\begin{array}{c}\text { interactional } \\
\text { Justice }\end{array}$ & Overall justice \\
\hline Organizational Trust & r-value & 0.579 & 0.528 & 0.631 & 0.709 \\
\cline { 2 - 6 } & P-value & $0.000^{*}$ & $0.000^{*}$ & $0.000^{*}$ & $0.000^{*}$ \\
\hline
\end{tabular}

Pearson correlation

* Statistical significant difference $(P<0.05)$

Table (5) : Correlation between organizational justice and Trust at Woman Reproductive Hospital.

\begin{tabular}{|c|c|c|c|c|c|}
\hline \multicolumn{2}{|c|}{ Items } & $\begin{array}{c}\text { distributive } \\
\text { Justice }\end{array}$ & $\begin{array}{c}\text { procedural } \\
\text { Justice }\end{array}$ & $\begin{array}{c}\text { interactional } \\
\text { Justice }\end{array}$ & $\begin{array}{c}\text { Overall } \\
\text { Justice }\end{array}$ \\
\hline \multirow{2}{*}{ organizational trust } & r-value & 0.602 & 0.612 & 0.691 & 0.719 \\
\cline { 2 - 6 } & P-value & $0.000^{*}$ & $0.000^{*}$ & $0.000^{*}$ & $0.000^{*}$ \\
\hline
\end{tabular}

Table (1) : Illustrated that, $(51.7 \%)$ of the study subjects are less than 40 years old. The great majorities of the study subjects are females $(92.0 \%)$ and $(76.3 \%)$ are married. Slightly more than half of them had secondary nursing school diploma $(53.0 \%)$, and $(29.0 \%)$ of nurses had 1-5 years of experience. The sample consisted mainly of staff nurses $(77.6 \%)$, and $(70.2 \%)$ of the study sample receive a salary ranging between $<500->999 \mathrm{LE}$ and less than half of them $(41.1 \%)$ take fringe benefits ranging between 50 - < 99 LE, there was a statistically significant difference between main ,pediatric and woman health reproductive hospital regarding to sex ,age ,job , qualification, years of experience and salary $\left(0.000^{*}\right.$, $0.002 *, 0.001 *, 0.006 *, 0.003 *)$ respectively.

Table (2) : is a comparison of the total mean scores of organizational justice, and trust assessed by nurses, at Assiut University Hospitals. It was found that there are statistically significant differences among hospitals regarding procedural justice, organizational trust, overall justice, and distributive justice (*P $\leq$ $0.000^{*}, 0.000^{*}, 0.001^{*}, \& 0.050^{*}$ ) respectively. It indicates no association of statistical significance regarding interactional justice and normative commitment.

In Table (3) : the correlation of the scores of organizational justice and organizational trust in the Main Hospital demonstrated significant and positive correlation between organizational justice and organizational trust $(\mathrm{r}=0.550)$, interactional justice and organizational trust $(\mathrm{r}=0.448)$, procedural Justice and organizational trust $(\mathrm{r}=0.427)$ and distributive Justice and organizational trust $(\mathrm{r}=0.421)$.

Table (4) : displays the correlation of the scores of organizational justice, organizational trust, and employees' commitment in Pediatric Hospital. The strongest positive statistically significant correlations were found between organizational justice and organizational trust $(\mathrm{r}=0.709)$, distributive Justice and organizational trust $(\mathrm{r}=0.579)$, procedural Justice and organizational trust $(\mathrm{r}=0.528)$ and interactional Justice organizational trust $(\mathrm{r}=0.631)$.

Table (5) : displays the correlation of the scores of organizational justice and organizational Trust. At Woman Reproductive Health Hospital. Strongest positive statistically significant correlations were found between organizational justice and organizational trust $(\mathrm{r}=0.719)$, distributive Justice and organizational trust $(\mathrm{r}=0.602)$, procedural Justice and organizational trust $(\mathrm{r}=0.612)$ and interactional Justice organizational trust $(r=0.691)$.

\section{Discussion}

Organizational justice primarily focuses on the fairness at workplace it puts stronger impact on different attitudes of the employees like turnover intentions, absenteeism, role breadth, job satisfaction, job performance, leader-member exchange, trust, leadership and organizational commitment (Bakhshi 
et al., 2009). It is a long time that specialists of Social Sciences \& Management found out the importance of social justice as a necessity for effectiveness in organizational processes (Noami et al., 2004).

The interpersonal treatment employees receive from their supervisor such as "adequately considering their view points, supporting their personal biases, explaining their decision and providing feedback timely and applying decision making criteria consistently" could have strong effect on the employee's perception of fairness. Therefore, organizations that have practices could increase their employee's trust in the organization and supervisors, which will in turn positively affect the levels of organizational commitment (Whitener, 2001).

This study was conducted with the aim of assessing the organizational justice and trust in Assuit university hospitals and studying the Relationship between organizational justice and trust.

According to this study seven hundred and twenty seven nurses belonging to Main, Pediatric, and Woman reproductive health hospitals were surveyed. The great majority of the study subjects were females $(92.0 \%),(76.3 \%)$ married, $(51.7 \%)$ were less than 40 years old. Slightly more than half of them had secondary nursing school diploma $(53.0 \%)$, and $(29.0 \%)$ of them had $1-5$ years of experience, $(70.2 \%)$ have salary ranged between 500 - 999 LE, and less than half of them $(41.1 \%)$ take fringe benefits between 50 - 99LE Table(1).

Regarding to gender the finding is in line with, Evans (2004). who mentioned that the history of nursing is almost exclusively a history of women's accomplishments despite the fact that, as early as the fourth and fifth centuries, men have worked as nurses. Moreover, Parsons and Reiss (2004). clarified that in reviewing the struggles that men in nursing have encountered in a predominantly female profession; one realizes that stereotypical attitudes do cross gender lines. The profession of nursing will only become stronger with gender diversity. Ragab (2008). mentioned that nursing is still primary a female profession and the woman who enter nursing are attracted to the care giving and nursing role.

Table (2) : revealed that interactional justice have the highest mean score for the three hospitals among the three justice component, this finding is consistence with the findings of Beugre (1996). study that interactional justice have the highest score among the four justice components. The implication is that justice issues are relevant and must be considered in relation to the interactions of individuals with others, i.e., in his or her relations with peers, superiors, subordinates, and the organization as a social system. Moreover Table (2) : revealed that there were statistically significant differences related to organizational trust between nurses in Pediatric hospital and Woman reproductive Health Hospital. This might be due to that pediatric nurse manager had the ability to involve nurses in decision making she also provide interpretation for all administrative decision that come from top managers and affect their work. Ruder (2003). mentioned that when employees believe in the organization values their contributions and cares about their well-being, they feel an obligation to reciprocate in a manner that helps the organization achieve its goals. In turn, employees trust that the organization will fulfill its exchange obligations (e.g., rewarding employees). Bahrami et al., (2012). clarified that trust has a significant role in increasing people's participation in the organization and improves their productivity. Trust among individuals and organizations can generate orderly and logical interactions among individuals

The present study declared that there is a strong positive statistically significant correlation between distributive justice and organizational trust. This is in the same line with the study finding of Saunders \& Thornhill (2003). who found that distributive justice has a close relationship to trust since feelings of trust are affected by the comparison to the relative treatment and outcomes of others. In the same respect Cohen \& Spector (2001). cited in Mahmoud (2012). have found that trust was similarly related to procedural and distributive justice. These results suggested that trust, for both the organization and the supervisor, is greatly impacted by an employee's perception of organizational justice.

As indicated by the present study results, there is a positive statistically significant correlation between procedural justice and organizational trust. The finding is congruence with Tyler and Blader (2003). studies that trust in management showed substantial unique effects of procedural justice. Procedural justice has been found to affect the evaluation of the organization and its authorities, and thus it would have strong impact on trust in organization. Arguably, employees will have a high level of trust in organization when they are guaranteed fair procedural treatment. Also, in agreement with the present study, Saekoo (2011). carried out a study of the relationships among trust, procedural justice, perceived organizational support, commitment, and job satisfaction. He found that procedural justice and perceived organizational support have positive impact on trust. Trust has non-sufficient impacts on commitment.

As indicated by the present study results, there is a positive statistically significant correlation between interactional justice and organizational trust. The result is in agreement with the finding of Bernerth et al., (2007). who found a 
close relationship between the way employees are treated by management and employees' trust in management hence; predict that interactional justice has a positive relationship with organizational trust.

On the same line, Colquitt (2001). contends that employees who are treated fairly in terms of interpersonal justice have trust for their managers. In relation, Cropanzano \& Greenberg (2001). asserted that social interaction like the nature and adequacy of information available and the extent to which employees are treated with fairness leads to trust in management.

Moreover the present study depicted that organizational justice has a positive impact on the organizational trust. This is in the same line with the study finding of Nakate (2007). who studied the relationship between organizational justice, employee trust, employee commitment and service quality. Results revealed a significant positive relationship between organizational justice and service quality, organizational justice and employee trust, organizational justice and employee commitment, employee trust and service quality and employee commitment was found to have a positive and significant relationship on service quality.

While Ponnu and Chuah (2010) stated that appraisal system mostly shifts their focus from distributive justice (outcomes) to procedural justice, which establishes grounds for trust and commitment. In addition distributive justice was found to be related to such work outcomes as pay satisfaction, job satisfaction, organizational commitment and trust in organizational.

Cropanzano et al., (2007). argued that fair process lead to intellectual and emotional recognition thus in turn creates the trust and commitment that build voluntary cooperation in strategy execution. Generally, the perception of justice is associated with job satisfaction, organizational commitment, and citizenship behavior, the intention of turnover, and the performance and organizational trust.

\section{Conclusions and Recommendations}

The following conclusions were drawn based on results of the present study

- The nurses' perception of interactional justice having the highest mean score for the three hospitals among the three justice component.

- The nurses' perception of organizational justice was significantly positive correlated with organizational trust and employees commitment

- The Pediatric Hospital nurses had the highest mean score as regard organizational justice, trust and commitment.
Based on the findings of the present study, the following recommendations are suggested

- Give the opportunities to all nurses to participate in decision making.

- Develop a "climate of fairness and trust" through making every one contribute.

- Create a competitive salaries system (e.g. payment based on performance).

- Nurse managers and nurses must work together to develop a climate of mutual trust and enhance commitment toward organization through:

- Guiding staff nurses with feedback, and using open communication.

- Develop policies for staff recruitment and performance appraisal.

- Staff nurses must be included in organizational committees.

- Applying leadership and management training for nurse managers.

\section{References}

1. Afsar B., and Saeed B., (2010) : Subordinate's Trust in the Supervisor \& its Impact on Organizational Effectiveness, The Romanian Economic Journal 15. 38 Pp4

2. Bahrami S., Rajaeepour S., Aghahosseni T., and Hodhodineghad N., (2012) : The relationship between organizational trust $\&$ nurse administrators' productivity in hospitals Iran J Nurs Midwifery Res. Sep-Oct; 17(6): Pp 451455.

3. Bakhshi A., Kumar K., and Rani E., (2009): Organizational Justice Perceptions as Predictor of Job Satisfaction \& Organization Commitment. International Journal of Business and Management; 4 (9): Pp 145-146

4. Bernerth J., Armenakis A., Feild H., and Walker J., (2007) : Justice, Cynicism, \& Commitment: A Study of Important Organizational Change Variables. The journal of applied behavioral science, 43(3), Pp 303-326.

5. Beugre' C., (1996) : Analyzing the effects of perceived fairness on organizational commitment and workplace aggression. Unpublished doctoral dissertation, Rensselaer Polytechnic Institute, New York Pp228-234

6. Cohen Y., and Spector P., (2001) : The role of justice in organizations: A meta-analysis. Organizational Behavior and Human Decision Processes, 86, Pp 278-324.cited by (Mahmoud A., 2012): Relation among work empowerment, organizational justice, respect and trust in nursing management and its association with nurses' job satisfaction and organizational 
commitment Master thesis. Alexandria : University of Alexandria ,Faculty of Nursing )

7. Colquitt J., (2001) : On the dimensionality of organizational justice: A construct validation of a measure. Journal of Applied Psychology, 86, Pp 386-400.

8. Cropanzano R., \& Greenberg J., (2001): Advance in organizational justice, Stanford, CA: Stantford University Press: Stantford, California Pp 89- 118.

9. Cropanzano R., Bowen D., \& Gilliland S., (2007) : The management of Organizational Justice. Academy of Management Perspectives. November pp34- $48 . \quad$ Available at:https://sharepoint.cahnrs.wsu. edu/extadmin/ bookshelf/ Documents/ The \%20 Management $\% 20$ of $\% 20$ Organizational \%20Justice .pdf

10. DeConick J., (2010) : The effect of organizational justice, perceived organizational support, and perceived supervisor support on marketing employees' level of trust. Journal of Business Research, 63, Pp 1349-1355.

11. Dirks K., \& Ferrin D., (2002) : "The role of trust in organizational settings", Organization Science, 12. 4, Pp. 450-67.

12. Evans J., (2004) : Men Nurses: A Historical and feminist perspective. J AdvNurs.; 47(3): Pp 321-8.

13. Johnson S., (2007): Organizational justice, moral ideology, and moral evaluation as antecedents of moral intent. Dissertation of $\mathrm{PhD}$, Virginia Polytechnic In statute and state university, Department of Human research development, Virginia, U.S.A.Pp96 -97

14. Mcnabb N., (2009): The dally Floggings will continue moral improves: an examination of the relationship among organizational justice, job satisfaction, organizational commitment and international to turnover. A Dissertation Submitted to the Graduate Faculty in partial fulfillment of the requirements for the degree of doctor of philosophy Chapter $1 \mathrm{Pp} 1$.

15. Nakate M., (2007): Organizational justice, employee commitment \& service quality in Uganda revenue authority. Thesis B.Sc. human resource management of Makerere University Pp3-43.

16. Noami A., Shokr K., \& Hossein R., (2004): Evaluation any simple and multiple relations of organizational justice and job satisfaction in employees of an industrial company, Training Sciences \& Psychology Magazine, Shahid Chamran Ahwaz University, 3rd Period, 11 th year, $1 \&$ 2, Pp 57-70.

17. Parsons L., \& Reiss P., (2004) : Breaking through the glass ceiling: women in executive leadership positions--Part I. 21(2): Pp100-2.
National Institutes of Health [PubMed - indexed for MEDLINE]

18. Ponnu C., and Chuah C., (2010): Organizational commitment, organizational justice \& employee turnover in Malaysia. Afr. J. Bus. Manag., 4(13): Pp 2676-2692. Available online

ISSN http://www.academicjournals.org/AJBM ISSN 1993-8233 (C2010 Academic Journals

19. Ragab S., (2008) : Effect of Locus of Control on Job stress and intent to Leave for Nurses at Assiut University Hospital Master thesis. Assiut : University of Assiut ,Faculty of Nursing

20. RebJ., Goldman B., Kray L., \& Cropanzano R., (2006) : Different wrongs, different remedies? Reaction to organizational remedies after procedural \& interactional injustice. Interactional in justice. Personnel psychology, 59(1), Pp 31-64

21. Ritter B., \& Lord R., (2007): The impact of previous leaders on evaluation of new leaders: An alternative to prototype matching. Journal of Applied Psychology, 92, (6), Pp.1683-1695.

22. Robbins S., \& Judge T., (2009): Organizational behavior (13th ed.). Upper Saddle River, NJ: Prentice Hall.

23. Ruder G., (2003) : "The relationship among organizational justice, trust, and role breadth self-efficacy". Dissertation submitted to the faculty of the Virginia Polytechnic Institute and State University for the Degree of Doctor of Philosophy in Human Development.

24. Saekoo A., (2011): Examining the effect of trust, procedural justice, perceived organizational support, commitment, and job satisfaction in Royal Thai police: the empirical investigation in social exchange perspective. ISSN: 1542-8710 Issue: Date: May, 2011 Source 11 Source Issue: 3 Pp36-64.

25. Salamon S., and Robinson S., (2008): Trust that binds: The impact of collective felt trust on organizational performance. Journal of Applied Psychology, 93, (3) Pp.593-601.

26. Saunders M., \& Thornhill A., (2003): Organizational justice, trust, \& the management of change. Personnel Review. 32.Pp 360-375.

27. Seyed J., SeyedR ., FarahI., Mohamad M., Taheri A., \& Qazaleh. (2008) : recognition of the effects of organizational justice dimensions on 38 various aspects of job and organizational satisfaction, Journal of Business Management, first. 1, Pp 55-70.

28. Turner E., (2010) : A corelational study of trust in an organization undergoing change A Dissertation Presented in Partial Fulfillment of the Requirements for the Degree Doctor of 
Management in Organizational Leadership University of phoenix Pp40.

29. Tyler T., \& Blader S., (2003) : The group engagement model: Procedural justice, social identity, and cooperative behavior. Personality and Social Psychology Review, 7, Pp349-361.

30. Whitener E., (2001) : "Do high commitment human resource practices affect employee commitment? A., cross-level analysis using hierarchical linear modeling", Journal of Management, 27. 5, Pp. 515-35.

31. Wong Y., Yuengo H., \& Sumwong C., (2004): Perceived Organizational Justice, Trust, \& OCB: A Study of Chinese Workers in Joint Ventures and State-owned Enterprises 10th ed chapter(2)Pp.3464http://jgxy.usx.edu.cn/DAOM/ 007-YuiTimWong

32. Young J., (2009): The Newcomer's Path to Trust: Trust- Building Strategies, Experienced Trust, and Employee Engagement among Newly-hired Employees 2nd ed Chapter (1) Pp .8-19. 